\title{
Correction to: The Routledge Handbook of the Politics of Migration in Europe
}

\section{A. Weinar, S. Bonjour and L. Zhyznomirska (eds). Routledge, London, 2019, 466 pp, ISBN: 978-1-138-20118-7}

\section{Christof Roos ${ }^{1}$}

Published online: 16 April 2019

(c) Springer Nature Limited 2019

\section{Correction to: Acta Politica https://doi.org/10.1057/s41269-019-00133-8}

In the original publication of the article, the last name of the third author of the handbook in the second line is wrongly spelled. The correct last name should be "Zhyznomirska".

The original article has been corrected.

Publisher's Note Springer Nature remains neutral with regard to jurisdictional claims in published maps and institutional affiliations.

The original article can be found online at https://doi.org/10.1057/s41269-019-00133-8.

Christof Roos

christof.roos@uni-flensburg.de

1 Europa-Universitat Flensburg, Auf dem Campus 1b, 24943 Flensburg, Germany 